\title{
Thermal Cosmetics as Therapeutic Adjuvant for Dermatological Disorders
}

\author{
André RTS Araujo ${ }^{1,2 *}$, Márcio Rodrigues ${ }^{1,2,3}$ Maximiano P Ribeiro $^{1,2,3}$ and Paulla Coutinho ${ }^{1,2,3}$ \\ ${ }^{1}$ Health Sciences School, Polytechnic Institute of Guarda, Av. Rainha D. Amélia s/n, 6300-749 Guarda, Portugal \\ ${ }^{2}$ CPIRN-UDI/IPG, Center of Potential and Innovation of Natural Resources, Research Unit for Inland Development (UDI), Polytechnic Institute of \\ Guarda, Av. Dr. Francisco Sá Carneiro, 50, 6300-559 Guarda, Portugal
}

${ }^{3}$ CICS-UBI, Health Sciences Research Centre, Faculty of Health Sciences, University of Beira Interior, 6200-506 Covilhã, Portugal

Submission: July 24, 2017; Published: October 24, 2017

*Corresponding author: André RTS Araujo, Health Sciences School, Polytechnic Institute of Guarda, Av. Rainha D. Amélia s/n, 6300-749 Guarda,

\begin{abstract}
Despite the various therapeutic applications and recommendations to the use of thermal waters in the prevention and/or treatment of various affections in different areas, several studies have confirmed the ability of the thermal waters to improve certain skin disorders. This work reports the mechanisms of action of thermal waters based on its physico-chemical composition and their clinical benefits for the development of new dermocosmetic formulations. These data justify the use of new biotechnological tools, such as innovative nanoscale delivery systems, to obtain a controlled release of the minerals present in the thermal water, that will act as an active or "cosmeceutical" ingredient in dermocosmetic formulations, aimed to prevent, support and treat skin disorders and also led to a significant improvement in quality of life of those patients.
\end{abstract}

Keywords: Cosmetics; Thermal waters; Dermatology; Biotechnology.

\section{Introduction}

Thermal waters are solutions formed under specific geological conditions and characterized by "physico-chemical dynamism". They share three fundamental properties: their natural origins from the earth 'springs', their bacterial purity and their therapeutic potential [1,2]. The therapeutic effects of thermal waters are attributed to their physico-chemical composition that is the base of the classification as bicarbonated, sulphated, chlorided, sulphurous, hyposaline and gasocarbonic waters [3].

In the past decades, an important change occurred in the clinical use of thermal water for the treatment of several diseases in continental Europe, mainly due to the increase in randomized clinical trials in dermatology and rheumatology areas, and therefore the medicinal thermalism assumes a valuable role. Actually, there is, even more, evidence that the treatment with thermalism water provides several beneficial effects for the prevention and in the treatment of different pathologies, and several studies confirmed the capacity/potential of these waters to support, improve or treat different disorders in the dermatological field.
The thermal waters used to treat dermatologic conditions present different identities in terms of physico-chemical profile. The mechanisms by which these diseases are treated in spa therapy are nowadays more fully justified and scientifically supported, involving chemical, thermal, mechanical and immunological effects on different dermatologic conditions, such as atopic dermatitis, contact dermatitis, seborrhea, seborrheic dermatitis, psoriasis and ichthyoses [3]. Indeed, thermal waters have demonstrated different effects on the skin, from cellular renewal, skin hydration, recovery of cutaneous barrier and keratolytic effects to antimicrobial activity, detergent property, antioxidant capacity and anti-inflammatory activity [4], that are associated with specific chemical elements, namely sulfur, silica, sodium, calcium and potassium, as previously reviewed [5].

When the skin is sensitive or presents disorders such as erythema, flaking, xerosis, etc., frequently associated with sensations of itching, redness or tightness, conventional cosmetics or dermatological products are insufficient to treat these disorders, and it is necessary the use of specific and adapted formulations to specific skin condition. Advances in skin 
biochemistry and physiology have allowed the development of specific products adapted to the different types of skin, dividing them according to the cosmetology characteristics that best fit and particularly when there are slight and/or moderate skin disorders [6]. Dermocosmetics or cosmeceuticals are a category of cosmetic products that integrate both dermatological and pharmaceutical considerations [7]. Cosmetics are able to improve the morphology and appearance of the skin through the activity of very specific components, being mainly used for nonaffected skin care or as an adjunct therapy in the treatment of skin diseases.

The beneficial effects of the thermal water in the treatment of some skin diseases justify its use of thermal waters as an active or "cosmeceutical" (or functional cosmetic) ingredient in dermocosmetic formulations. In fact, once thermal waters are rich in minerals and oligoelements with proved dermatological indications, they can be considered as a perfect raw material to dermocosmetic formulations, and these later are widely recognized by the capacity to encapsulate, stabilize and carry these elements. These dermocosmetics will be applied to improve the skin's properties in terms of hydration, flexibility and elasticity, as well as to promote the different effects of the thermal waters, such as anti-inflammatory, calmative, desensitizing, healing and antioxidant effects $[8,9]$.

One of the biggest problems for dermocosmetics with hydrophilic ingredients such as thermal water is the penetration onto the skin, once the outermost layer (stratum corneum of the epidermis) is hydrophobic. Once the therapeutic effects of the thermal waters are due to the interaction between the active components of the water and the structure of the skin surface, the development of dermocosmetic formulations to provide a controlled release of such hydrophilic bioactive components is crucial and an attractive challenge. With this scope, the cosmeceutical/cosmetics industry has been applying nanobiotechnology in the creation and incorporation of new and effective delivery systems in their products. Nanotechnology today offers a broad range of techniques to produce different nanocarriers for transporting hydrophilic substances like thermal water. The properties of the nanocarrier systems such as size, hydrophobicity and charge are fundamental in the controlled release to increase the permeation/penetration of the water on the skin, which in turn enhances the biological effects of thermal waters. Indeed, these systems have the added advantage of preserving the original and unique properties of thermal waters and ensure the stability of the other active components over greater periods [3].

\section{Conclusion}

Considering this it is proposed the development of specific and nonresponsive dermocosmetic formulations based on thermal waters, that exhibit unique physico-chemical features, to contribute to the improvement of treatment of dermatological disorders and, overall, to the comfort and well-being of the skin. After the adequate biometric testing to evaluate the effectiveness and safety, these new-thermal-water-based cosmetics could represent an important contribution to the cosmetic field, as well as for the treatment of specific organic or functional skin disorders, either solely or as an adjuvant to more specific treatments.

\section{Acknowledgements}

Authors acknowledge to the Fundação para a Ciência e Tecnologia (FCT) Fundo Europeu de Desenvolvimento Regional (FEDER) and COMPETE 2020 for the financial support under the research project "The development of dermo-biotechnological applications using natural resources in the Beira and Serra da Estrela regions - DermoBio" with no.023925, presented in the Notice for the Presentation of Applications No. 02 / SAICT / 2016 - Scientific Research and Technological Development Projects (IC \& DT) in Co-Promotion.

\section{References}

1. Ghersetich I, Freedman D, Lotti T (2000) Balneology today. J Eur Acad Dermatol 14(5): 346-348.

2. Matz H, Orion E, Wolf R (2003) Balneotherapy in dermatology. Dermatol Ther 16(2): 132-140.

3. Araujo ARTS, Paiva T, Ribeiro MP, Coutinho P (2015) Innovation in Thermalism: An Example in Beira Interior Region of Portugal. In: Peris-Ortiz M, Álvarez-García J [Eds.], Health and Wellness Tourism, Springer-Emergence of a New Market Segment, pp. 165-180.

4. Nunes S, Tamura BM (2012) A historical review of mineral water. Surg Cosmet Dermatol 4(3): 252-258.

5. Araujo ARTS, Sarraguça MC, Ribeiro MP, Coutinho P (2017) Physicochemical fingerprinting of thermal waters of Beira Interior region of Portugal, Environ Geochem Health 39 (3): 483-496.

6. Ghersetich I, Brazzini B, Hercogova J, Lotti TM (2001) Mineral Waters: Instead of cosmetics or better than cosmetics? Clin Dermatol 19(4): 478-482.

7. Kerscher M (2009) Aesthetic and cosmetic dermatology. Eur J Dermatol 19(5): 530-534.

8. Faílde RM, Mosqueira LM (2006) Afecciones dermatol gicas y cosmética dermotermal. In: Torres AH [Eds.], Técnicas y Tecnolog as en Hidrología Médica e Hidroterapia, Agencia de Evaluación de Tecnologías Sanitarias (AETS), Instituto de Salud Carlos III-Ministerio de Sanidad y Consumo, Madrid,175-194.

9. Mourelle, ML, Gómez CP Legido J L (2015) Cosmética dermotermal: valor añadido para los centros termales. $1^{\text {st }}$ International Symposium on Healing SPA and Life Quality, Campus da Auga, Vicerrectoría del Campus de Ourense, Ourense, Spain, pp. 389-398. 


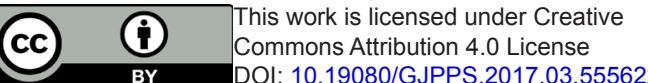

BY DOI: 10.19080/GJPPS.2017.03.555622
Your next submission with Juniper Publishers will reach you the below assets

- Quality Editorial service

- Swift Peer Review

- Reprints availability

- E-prints Service

- Manuscript Podcast for convenient understanding

- Global attainment for your research

- Manuscript accessibility in different formats

( Pdf, E-pub, Full Text, Audio)

- Unceasing customer service

Track the below URL for one-step submission https://juniperpublishers.com/online-submission.php 